\title{
Development of guided discovery learning model worksheet on sequences and series in vocational schools
}

\author{
Fimatesa Windari ${ }^{1}$, Armiati $^{2}$, Yulkifli ${ }^{3}$ \\ ${ }^{123}$ Universitas Negeri Padang, Padang - Indonesia, (fimatesawindari@gmail.com)
}

\begin{abstract}
Students' worksheet is one of learning media to help students in studying mathematics. The worksheet is based on guided discovery learning. It is aimed to get the students accostumed in inventing mathematics concept, therefore the worksheet can make it easier for the students to understand sequences and series material. Sequences and series is one of the essential materials tought in vocational school since it is often correlated to problem solving. In general, the students in vocational school lack of ability to do problem solving. This research used Plomp educational design research that consist of initial preliminary research, development or prototyping stage and assesment phase. The instrument used in this research was validation sheet of students' worksheet. The aim of this research was to produce valid, practice and effective worksheet. The result of this research showed that the Guided Discovery Model worksheet on Sequences and Series was valid, practical and effective.
\end{abstract}

Keyword: worksheet, guided discovery learning, plomp

\section{Introduction}

Worksheet is one of the teaching materials used by teachers to help learning process. In every learning process, students are expected to be able to achieve learning objectives. One of the objectives of learning is that learners have the ability to understand concepts and to solve mathematical problems. Based on observations on one of vocational school in Padang, it can be seen that the students lack ability of understanding the concept and solving mathematical problems. One of the important materials that have a small number of students who passed learning mastery is the topic of sequence and series. Therefore it is necessary to create a worksheet that can improve the ability of understanding the concept and problem solving on the topic of sequence and series. One of the worksheets that can improve students' understanding of concept and ability to solve mathematical problem is a guided discovery model worksheet.

The mental process of students in assimilating a concept or a principle is called the discovery defined by Suryosubroto [2]. The mental processes in this case are observing, grouping, hypothesizing, explaining, measuring, making conclusions and so forth. While, according to Jerome Bruner in Markaban [3] discovery is a process. Learning by discovering is learning to discover and find a way of solving the problem or certain situation given. In the implementation of the Guideddiscovery learning model according to Sudjana [4], it has to meet several conditions, such as: a) the 
problems given are in accordance with the students' reasoning ability. b) Teachers have to be skilled at fostering students' motivation and creating enjoyable learning situations. c) Adequate facility and learning resources are available. d) The freedom of students to argue, work and discuss. e) Participation of each learner in every learning activity. f) Teachers do not interfere and intervene on students' activities. According to Kurniasih and Sani (2014: 30-33), the operational steps of guided discovery learning are as follows: Stimulation; Problem statement; Data Collection; Data processing; Verification; Generalization.

\section{Method}

This research used Plomp educational design research. The guided discovery-based learning media that will be developed refers to the three-stage Plomp model, the preliminary research phase, the development or prototyping phases, and the assessment phase [1]

At the preliminary research stage, the researcher performs a needs analysis to create worksheet based on guided discovery. The main steps that must be done are as follows.

a. Needs Analysis

In the needs analysis phase, information about the problems in learning mathematics is gathered. The information gathering was done by interviewing some students and teachers of SMKN 2 Padang Management and Business Department. As well as observing the learning media at the research site and learning activities as well as analyzing existing worksheet. Based on the results of observations and interviews, it is required to do innovation and updates that can support the learning process and students' learning outcomes.

b. Curriculum Review

This analysis was done to answer the following questions: 1) what curriculum does the school use? 2) What are the Core Competence and Basic Competence in the curriculum used in the odd semester of Business Management Vocational school on sequence and series? 3) Are the Core Competence and Basic Competence formulated sufficient to achieve the curriculum objectives? If not, what to add? 4) Are the Core Competence and Basic Competence formulated well sorted? If not, what order should be? Why is that? 5) Do the formulated indicators include competency achievement? If not, what to add?

The results of this analysis serve as a reference in determining the range of materials needed to achieve the learning objectives. To answer those questions, data collection with the instrument used in the form of checklist is conducted.

c. Analysis of Learners

In this analysis, interviews were conducted with teachers. To obtain the information, then the analysis of the students is done to answer the following questions: 1) what is the academic ability of students of class X Business Management Vocational School in mathematics lesson? 2) What kind of mathematical learning do students expect? 3) What kind of worksheet does the learner want, to facilitate them in learning mathematics? 4) What animations or pictures do the students prefer to be displayed in the worksheet that will be developed? 5) What colors are preferred by learners to increase desire in learning? To answer these questions, data collection through the questionnaire is done.

d. Concept Analysis

At this stage the activities of identifying, detailing, and systematically compiling the main materials learned by learners on the topic of sequence and series.

In the development or Prototyping Phase, Worksheet was arranged based on guided discovery. Components that have to be existed in the validation sheet based on MoNE [5] include the feasibility of language, content, and graffiti. The worksheet was created is based on analysis results at the preliminary research stage. In making this prototype, formative evaluation was done to improve the validity and practicality. With the explanation as follows: 
a) Self-evaluation, which is a prototype evaluation that has been designed by the researchers themselves. The purpose is to check the lack of letters in the words and components contained in the worksheet.

b) Expert review is to ask expert or relevant experts to provide an assessment and input to the designed prototype by validating worksheet based on guided discovery model. Validation of learning media based on the guided discovery model includes the content and validity of the constructs.

c) One-on-one evaluation is conducted by asking the product user's namely the students suggestion (high ability, moderate and low ability students) to assess the product. The purpose of a one-toone evaluation is to identify possible errors such as poorly understood grammar, improper spelling, unclear instructions, attraction, time efficiency and the advantage of worksheet.

d) Small group evaluation is done by asking 6 students (high-ability, moderate and low) to use learning media based on guided discovery model. The purpose of the small group is to see the practicality of the device that includes the acceptance of learners, the implementation, the appropriateness of the time allocation, the ease of using of the learning media.

e) Field Test was conducted by using guided discovery worksheet on learning in class X of Business Management Vocational School Padang. Field trials are also conducted to see the practicality of guided discovery worksheet by looking at the practicality level of learning media when they were used in the learning process since this material will be taught in school when research was conducted. The instruments are observation sheet and questionnaire.

The assessment phase is done by looking at the improvement of the students' ability to understand the concept and solve mathematical problems.

\section{Results and Discussion}

The purpose of this research is to produce a practical and effective guided discovery learning based media. With the following phases:

1. The preliminary research phase,

a) Needs Analysis; at this stage it is seen that the teaching materials used by the teacher is inadequate so that most of the learners get value under Minimum Mastery Criteria. Therefore it is necessary to renew the form of guided discovery worksheet based that can help the learning process.

b) Curriculum Review; the curriculum used is the 2013 curriculum. Generally the indicators used for guided discovery models worksheet on the sequence and series of materials contained in the syllabus. However, there are things that need to be appreciated by Audience, Behavior, Condition and Degree.

\begin{tabular}{|c|c|c|}
\hline $\begin{array}{c}\text { Basic } \\
\text { Competence }\end{array}$ & Indicators on Syllabus & $\begin{array}{c}\text { Indicators of Competence } \\
\text { Achievement }\end{array}$ \\
\hline $\begin{array}{l}\text { Analyzing } \\
\text { arithmetic } \\
\text { sequence and } \\
\text { series }\end{array}$ & $\begin{array}{l}\text { 1. Analyzing and } \\
\text { discovering the concept } \\
\text { of arithmetic sequence. } \\
\text { 2. Analyzing and } \\
\text { discovering the concept } \\
\text { of arithmetic series. }\end{array}$ & $\begin{array}{l}\text { 1. Given problems related to } \\
\text { arithmetic, students are able to } \\
\text { analyze and discover the } \\
\text { concept of arithmetic sequence } \\
\text { in group carefully and } \\
\text { thoroughly } \\
\text { 2. Given problems related to } \\
\text { arithmetic, students are able to } \\
\text { analyze and discover the } \\
\text { concept of arithmetic series in } \\
\text { group carefully and thoroughly }\end{array}$ \\
\hline
\end{tabular}

Figure1.The result of Analysis of Competency Achievement Indicator Formulation 
c) Students' Analysis; in general the academic ability of students of class X Business Management Vocational school in mathematics are low. From the results of the analysis, there are 23 out of 33 students like group learning in the classroom. either in pair with a chair mate or in group of four. In addition, 18 out of 33 students like the colorful learning resources and 11 out of 33 students like learning resources that were easy to understand and the sentences were not too long. For color, 20 out of 33 students love the green color. This is because the color of green has a cool impression and make students eager to learn.

d) Concept Analysis; Conceptual analysis is conducted to identify, detail, and systematically compile the main materials learned by students on the topic of sequence and series. The sequence and series materials to be developed are arithmetic sequences, arithmetic series, geometric sequences, geometric series and growth and decay.

2. The Development or Prototyping Phases

The worksheet was made based on preliminary research data that has been implemented. it is made in accordance with the components contained in the worksheet (MoNE, 2008: 23-24), ie (i) title, (ii) instructional guidance, (iii) competence to be achieved, (iv) supporting information, ( v) tasks and work steps, (vi) assessment. The activities contained in the worksheet are adjusted to the guided discovery model. Then a formative evaluation is conducted which was aimedto improve validity and practicality. With the explanation as follows:

a) Self-evaluation

In the results of the self-evaluation, there is an inconsistency with the language used. Like some use the word "student" and some use the word "learners". In addition there are punctuation errors that have to be fixed such as the use of punctuation, commas and capital letters.

b) Expert review; the worksheet validation is performed by 5 validators i.e. 3 mathematics education experts, 1 Indonesian language expert and 1 educational technologist to validate the display aspect. During the validation process there are several revisions suggested by the validators. The following is a recapitulation of worksheet validation results by validators:

Table 1. Recapitulation Result of Worksheet Validation

\begin{tabular}{clcc}
\hline No. & \multicolumn{1}{c}{ Validation Aspect } & Validity Index & Category \\
1. & Didactic and Material & 3,11 & Valid \\
2. & Language & 3,13 & Valid \\
3. & Graffiti & 3,00 & Valid \\
\multicolumn{2}{l}{ The Average of Validity Indexes } & 3,08 & Valid \\
\hline
\end{tabular}

Based on Table 1 above, it appears that in general the didactic, linguistic and graffiti aspects have met the valid criteria with an average of 3.11; 3.13 and 3.00. Overall validity of worksheet based on guided discovery model has fulfilled the valid criterion with the average of 3.08 total indexes.

c) One-to-one evaluation;

One-to-one evaluation is conducted in 6 meetings. The activity was done by the students to observe clues and sentences that are difficult to understand, taking responses and suggestions note about the worksheet. Implementation of individual evaluation stage can be seen in Figure 2 below: 

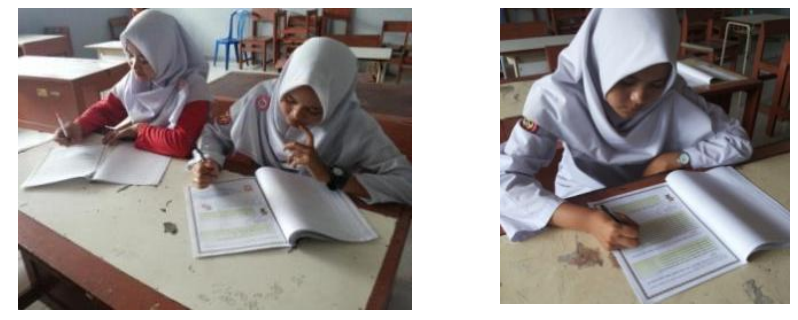

Figure2. One-to-one evaluation

On this stage there are several revisions that need to be done by the researcher. Such as the use of language that is less understood by students. The planned time allocation does not suitable with the implementation. Therefore, it needs to be revised in the exercise section and for the unfinished numbers, made as tasks at home.

d) Small group evaluation. In small group evaluation, it is done by practicing the designed media by the students in a group of 6 who will be divided into 2 people each group. For small group evaluation, generally students have understood guided discovery model worksheet. However, there are still some revisions on the algebraic analysis section in finding arithmetic array formulas since the students still have difficulties in explaining how the general form of arithmetic series can be found.

e) Field Test; learners who have followed all learning using guided discovery-based worksheet are given a questionnaire. Questionnaire was given to students of class X B 3 SMKN 2 Padang with a total of 32 people.

Table 2. Results of Student Response to Guided Learning Model-Based Worksheet Questionnaire

\begin{tabular}{clcc}
\hline No & \multicolumn{1}{c}{ Rated aspect } & Average & Category \\
I. & Ease of Use & 3,34 & Practical \\
II & Time efficiency & 3,19 & Practical \\
III. & Ease of comprehending & 3,23 & Practical \\
IV. & The Advantage of worksheet & 3,33 & Practical \\
& Overall Average & 3,29 & Practical \\
\hline
\end{tabular}

Based on the above table, it can be seen that the average level of Guided Discovery based worksheet according to the students' response is 3.29 with practical category based on practical criterion. From the results of questionnaires filled by the students, the worksheet was easy to use, motivate students to learn math, facilitate students in understanding the concept of mathematics. Thus, it can be concluded that Guided Discovery models based worksheet are practicable according to the students' responses.

\section{Assessment Stage.}

At the assessment stage, the ability to understand the concept of understanding and solving the mathematical problems of the students is shown on the following table:

Table 3. Results of Concept Understanding Skill

\begin{tabular}{lc}
\hline \multicolumn{1}{c}{ Indicator of Concept Understanding Skill } & Percentage of ideal scores \\
Classifying Objects by certain characteristic & $90 \%$ \\
Presenting Objects in various mathematical representations & $80 \%$ \\
Reiterating a concept & $85 \%$ \\
Using, utilizing and selecting particular procedures or & $65 \%$ \\
operations & \\
Applying concepts or algorithms on problem solving & $62 \%$ \\
$\quad$ Average & $76,4 \%$ \\
\hline
\end{tabular}


Based on the above table, it can be seen the percentage of the ideal score of each indicator. In the indicator classifying objects according to certain characteristic, $90 \%$ of students managed to get an ideal score, meaning that most students are able to classify objects according to certain traits. Some students do not achieve the ideal score because they are not able to understand the problem well. This is because the students' answers are not complete or some answers are still wrong. In the indicator presenting the object in the form of mathematical representation and reiterating a concept, the percentage of students who get the ideal score is $80 \%$ and $85 \%$. In the indicators using and utilizing as well as selecting a particular procedure or operation and applying concepts or algorithms on problem solving the percentage of ideal scores is only $65 \%$ and $62 \%$. Some learners who have not achieved an ideal score because they have not been able to solve the problem well or the answer were still wrong.

Table 4. Results of the Ability to Do Problem Solving

\section{Problem solving indicators}

Understanding the Problem

Planning a Solution

Solving the problem

Re-checking
Ideal Score Percentage

$83 \%$

$80 \%$

$70 \%$

$45 \%$

$69,5 \%$

The above table shows the ideal score percentage of each indicator. In the indicators understanding the problem, $83 \%$ of students managed to get an ideal score, meaning that most learners are able to understand the problem by constructing their own knowledge. Some students do not achieve the ideal score because they are not able to understand the problem well. This is because the students' answers are not complete or some answers are still wrong.

In the indicators of planning a solution and solving the problem, the percentage of students who get the ideal score is $80 \%$ and $70 \%$. On the re-checking indicator the ideal percentage score is only $45 \%$. This is because to be able to check back the results obtained by the previous students should be able to solve the problem first. Some students have not achieved an ideal score because they have not been able to solve the problem well or the answers were still wrong.

From the above table the ability to understand the concept of understanding and problem solving obtained an average of 76.4 and 69.5. It can be concluded that the learning media based on the guided discovery model are effective to improve the ability of concept comprehension and solving mathematical problem.

\section{Conclusion}

The results of the research are as follows:

1. Guided discovery model-based worksheet developed for sequence and series material has been valid.

2. Guided discovery model-based worksheet developed for sequence and series material has been practical.

3. Guided discovery model-based worksheet developed for sequence and series material has been effective

With the results of this study, it can be said Guided discovery model-based worksheet on sequences and series can help teachers in the process of learning. 


\section{Acknowledgments}

A special gratitude to Allah SAW who has provided the opportunity, blessings and grace to complete this research and the supervisors who have provided guidance and direction to complete this research. Then to teachers and students majoring Accounting of SMKN 2 Padang who became the subject of this research.

I acknowledge that this study has many limitations. I apologize for the weaknesses. Hopefully all readers can give criticism and input to improve this journal.

\section{References}

Plomp, Tjeerddan Nieken Nieveen. (2013). Educational Design Research.Enshede: Netherlands Institute for Curriculum Development (SLO).

Suryosubroto.(2009). Proses Belajar Mengajar di Sekolah. Jakarta: Rineka Cipta

Markaban.(2008). Model Pembelajaran Matematika dengan pendekatan Penemuan Terbimbing. Yogyakarta: Depdiknas.

Sudjana, Nana. (2008). Dasar-dasar Proses Belajar Mengajar. Bandung: Sinar Baru Algesindo.

Depdiknas.(2008). Panduan Pengembangan Bahan Ajar. Jakarta: Direktorat Jenderal Manajemen Pendidikan Dasar dan Menengah. 